\title{
Osteogenic Gene Expression Correlates With Development of Heterotopic Ossification in War Wounds
}

\author{
Korboi N. Evans MD, MS, Benjamin K. Potter MD, Trevor S. Brown PhD, \\ Thomas A. Davis PhD, Eric A. Elster MD, Jonathan A. Forsberg MD
}

Received: 4 June 2013/Accepted: 30 September 2013/Published online: 18 October 2013

(C) The Association of Bone and Joint Surgeons \& 2013

\begin{abstract}
Background Heterotopic ossification (HO) is a frequent complication of modern wartime extremity injuries. The biological mechanisms responsible for the development of $\mathrm{HO}$ in traumatic wounds remain elusive.

Question/purposes The aims of our study were to (1) characterize the expression profile of osteogenesis-related gene transcripts in traumatic war wounds in which $\mathrm{HO}$
\end{abstract}

Funding for this study was received from the US Navy Bureau of Medicine and Surgery under the Medical Development Program (PE $0604771 \mathrm{~N}$, Principal Investigator EAE).

All ICMJE Conflict of Interest Forms for authors and Clinical Orthopaedics and Related Research editors and board members are on file with the publication and can be viewed on request. Each author certifies that his or her institution has approved the human protocol for this investigation and that all investigations were conducted in conformity with ethical principles of research.

The views expressed in this article are those of the authors and do not necessarily reflect the official policy or position of the Department of the Army, the Department of the Navy, Department of Defense, nor the US Government. This work was funded by work unit number 601153 N.4508.5180.A0508. The authors are military service members (or employees of the US Government). This work was prepared as part of their official duties. Title 17 U.S.C. 105 provides that "Copyright protection under this title is not available for any work of the United States Government." Title 17 U.S.C. 101 defines a US Government work as a work prepared by a military service member or employee of the US Government as part of that person's official duties.

This work was performed at the Walter Reed National Military Medical Center and the Naval Medical Research Center, Bethesda, MD, USA.

K. N. Evans, T. S. Brown, T. A. Davis, E. A. Elster,

J. A. Forsberg $(\square)$

Regenerative Medicine Department, Naval Medical

Research Center, 503 Robert Grant Avenue, Silver Spring, MD 20910, USA

e-mail: jonathan.a.forsberg@health.mil; jaforsberg@me.com developed; and (2) determine whether expression at the mRNA level correlated with functional protein expression and $\mathrm{HO}$ formation.

Methods Biopsy specimens from 54 high-energy penetrating extremity wounds obtained at the initial and final surgical débridements were evaluated. The levels of selected osteogenic-related gene transcripts from RNA extracts were assessed by quantitative reverse transcriptase-polymerase chain reaction (RT-PCR) analysis. As a result of its key role in osteogenesis, the concentration of BMP-2 in the effluent of 29 wounds also was determined. Results The transcripts of 13 genes (ALPL [p $=0.006]$, BMP-2 [p $<0.001], \quad$ BMP-3 $[\mathrm{p}=0.06], \quad$ COL2A1 [p $<0.001], \quad$ COLL10A1 [p $<0.001], \quad$ COL11A1 $[\mathrm{p}=0.006]$, COMP $[\mathrm{p}=0.02], \mathrm{CSF} 2$ [p $=0.003], \mathrm{CSF} 3$ $[\mathrm{p}=0.012]$, MMP8 [p $<0.001]$, MMP9 [p $=0.014]$, SMAD1 [p $=0.024]$, and VEGFA $[\mathrm{p}=0.017]$ ) were upregulated greater than twofold in wounds in which $\mathrm{HO}$ developed compared with wounds in which it did not develop. Gene transcript expression of BMP-2 also correlated directly with functional protein expression in the wounds that formed $\mathrm{HO}(\mathrm{p}=0.029)$.

Conclusions Important differences exist in the osteogenic gene expression profile of wounds in which HO developed compared with wounds in which it did not develop. The upregulation of multiple osteogenesis-related gene transcripts indicates the presence of a proosteogenic environment necessary for ectopic bone formation in traumatic wounds.

K. N. Evans, B. K. Potter, J. A. Forsberg

Department of Orthopaedics, Walter Reed National Military Medical Center, Bethesda, MD, USA 
Clinical Relevance Understanding the osteogenic environment associated with war wounds may allow for the development of novel therapeutic strategies for HO.

\section{Introduction}

Heterotopic ossification (HO) is the formation of mature lamellar bone in soft tissue. Familial forms of the condition include progressive osseous heteroplasia and Albright hereditary osteodystrophy [48]. Recurrent mutations in the BMP type-1 receptor, activin receptor IA (ACVR1), and local changes in the expression of BMP-4 and its receptor (BMPR1A) have been linked to the rare genetic disorder fibrodysplasia ossificans progressiva $[11,13,18,20,26]$. The more common acquired forms of $\mathrm{HO}$ frequently occur as a complication of THA, elbow or acetabular fractures requiring surgical treatment, soft tissue injury secondary to trauma or deep muscle dissection, and traumatic brain or spinal cord injuries [3, 7, 8, 25, 49].

Regardless of etiology, it is theorized that the pathogenesis of HO requires several factors, the first being an inducing agent or event. This can be the result of closed or penetrating trauma resulting in damage to the bone or surrounding musculature. The concomitant hematoma may then deliver the mesenchymal progenitor cells or committed osteoblast precursor cells from the surrounding tissue or systemic circulation. Finally, an environment conducive to osteogenesis primed by local and systemic mediators is required [13]. As such, injured soft tissues in the setting of a dysregulated posttraumatic inflammatory response may represent an ideal environment for the dysplastic differentiation of mesenchymal stem cells toward osteoblastic lineage and ectopic bone formation [37].

Heterotopic ossification has proven to be a common and problematic complication of modern wartime extremity injuries, and it causes patient morbidity and loss of function [16, 39]. Studies suggest the rate of ectopic bone formation in combat-related injuries is substantially higher than prior estimates reported in civilian trauma populations $[16,39]$. Despite several studies investigating systemic factors and the in vitro measurement of osteoblastic activity of cells from heterotopic bone [2, 27, 45], the biological mechanisms responsible for $\mathrm{HO}$ as a result of traumatic injury have not been defined.

B. K. Potter, E. A. Elster, J. A. Forsberg

Department of Surgery, Uniformed Services University

of Health Sciences, Bethesda, MD, USA

E. A. Elster

Department of Surgery, National Naval Medical Center, Bethesda, MD, USA
Advances in molecular profiling technologies have identified effector molecules, transcription factors, and regulatory genes involved in the tightly regulated process of bone metabolism [1]. A similar understanding of the molecular and cellular mechanisms associated with ectopic bone formation may lead to targeted therapies aimed at effective prevention, diagnosis, and treatment for patients with or at risk of HO. Given the high prevalence of $\mathrm{HO}$ in combat-related wounds, we asked whether expression at the mRNA level would correlate with the development of radiographically apparent $\mathrm{HO}$.

The aims of our study were (1) to characterize the expression profile of osteogenesis-related gene transcripts in traumatic war wounds in which HO developed; and (2) determine whether expression at the mRNA level correlated with functional protein expression and $\mathrm{HO}$ formation.

\section{Patients and Methods}

To determine the expression level of gene transcripts involved in the development of $\mathrm{HO}$ in traumatic wounds, 34 wounded US service members with 54 wounds were enrolled in this prospective observational study. We included patients with high-energy, penetrating extremity wounds $\left(<75 \mathrm{~cm}^{2}\right)$ to one or more extremities, which were evacuated to the National Naval Medical Center from combat zones within Iraq and Afghanistan. Those with confounding premorbid systemic conditions including diabetes, immune disorders, connective tissue disorders, or any conditions requiring immunosuppressive agents and patients with prior extremity surgery complicated by infection were excluded and not enrolled. All patients were male with a mean age of 23.4 (range, 18-42 years) who presented to our institution a mean 5.6 (SD 2.6) days after having undergone intercontinental aeromedical evacuation from theater through Landstuhl Regional Medical Center in Germany. Up to three extremity wounds per patient were studied. In patients with more than three wounds, the largest three wounds were chosen for analysis based on wound volume $\left(\mathrm{cm}^{3}\right)$ from clinical and radiographic measurements and calculations from digital photographs using PictZar ${ }^{\circledR}$ planimetry software (BioVisual Technologies, Elmwood Park, NJ, USA). All patients underwent surgical débridement every 48 to 72 hours after arrival at our institution until definitive wound closure or coverage. Wound effluent from the vacuum-assisted wound closure device without a gel-pack (V.A.C. ${ }^{\circledR}$; Kinetic Concepts, Inc, San Antonio, TX, USA) and a $1-\mathrm{cm}^{3}$ tissue biopsy specimen from the center of the wound bed were obtained prospectively at each surgical débridement. Tissue biopsy specimens were placed in an RNA preservation medium (RNAlater $^{\mathrm{TM}}$; Ambion Inc, Austin, TX, USA) and all 
samples stored at $-80^{\circ} \mathrm{C}$ until analysis. Bacterial colonization and eventual wound outcome also were defined as previously described [22]. Colonization was defined as greater than $10^{4}$ total bacteria on tissue-based quantitative bacteriology using standard techniques. The study was approved by the institutional review boards of the National Naval Medical Center and the Naval Medical Research Center. All patients signed informed consent to participate in this study and one patient died and thus was lost to followup.

Biopsy specimens from the 54 wounds obtained at the initial and final surgical débridements before definitive closure or soft tissue coverage were used for analysis to explore the temporal pattern of expression. Our power analysis indicated that 10 wounds per group were required to have an $80 \%$ power to detect a twofold threshold of differential gene expression (SAS, Cary, NC, USA). Total RNA was extracted and purified according to the manufacturer's instructions using the RNeasy ${ }^{\circledR}$ Fibrous Tissue Mini Kit (Qiagen Inc, Valencia, CA, USA) from $30 \mathrm{mg}$ of tissue sample after homogenization. The samples were incubated in the presence of DNase 1 to minimize genomic DNA contamination. RNA quantity and purity were assessed spectroscopically using the NanoDrop Spectrophotometer (NanoDrop Technologies Inc, Wilmington, DE, USA) and RNA integrity assessed by microcapillary electrophoresis (Agilent 2100 BioAnalyzer; Agilent Technologies Inc, Santa Clara, CA, USA). RNA integrity values for all samples in this study were 7.0 or greater. Using the $\mathrm{RT}^{2}$ First Strand Kit (SABiosciences, Frederick, MD, USA), $1 \mu \mathrm{g}$ of total RNA was reverse-transcribed into cDNA for quantitative reverse transcriptase-polymerase chain reaction (RT-PCR). A commercially available low-density RTPCR array of 96 primer sets (including respective forward and reverse primers) for 84 osteogenesis-focused, five housekeeping, and seven quality control genes (SABiosciences, Gaithersburg, MD, USA) was used to assess gene expression in duplicate. Quantitative RT-PCR and dissociation curve analyses were performed using the $\mathrm{ABI}$ PRISM $^{\circledR}$ 7900HT Sequence Detection System (Applied Biosystems, Foster City, CA, USA) with SYBR ${ }^{\circledR}$ Green (SABiosciences) detection. Amplification parameters were as follows: one cycle of $50^{\circ} \mathrm{C}$ for 2 minutes and $95^{\circ} \mathrm{C}$ for 10 minutes followed by 40 cycles of $95^{\circ} \mathrm{C}$ for 30 seconds and $60^{\circ} \mathrm{C}$ for 1 minute. RT-PCR data were analyzed using the Sequence Detection System Version 2.1 included with the ABI Prism 7900HT SDS and Microsoft Excel. The threshold was manually set and the baseline was set automatically to get the threshold cycle $(\mathrm{Ct})$ value for each target. GAPDH was used as an endogenous housekeeping control gene for normalization. HO and non-HO samples were run in duplicate wherein $\mathrm{Ct}$ measurements per samples were normalized using GAPDH. Relative expression between $\mathrm{HO}$ and non-HO tissue was determined using the comparative $\mathrm{Ct}$ method $(2-\Delta \Delta \mathrm{Ct})$ [31]. Results are expressed as the mean $\pm \mathrm{SD}$ difference in relative expression. Transcription of a particular gene transcript in BMMSCs was considered to be differentially up- or downregulated if it was differentially expressed by at least twofold when compared with the expression level in HSPCs and vice versa for the reverse analysis. Assays with $\mathrm{Ct}$ values greater than 35 cycles were excluded from analysis.

HO was defined as the formation of ectopic matrix mineralization in soft tissues evident on routine AP and lateral radiographic views of the involved extremity at a minimum of 2 months after injury, as previously described $[17,39]$. The minimum time for radiographic followup was selected based on previous studies from this and other surgical patient populations showing that $\mathrm{HO}$ is reliably evident radiographically within 2 months of the inciting event $[4,16,34,35,39]$. A two-author blinded independent review of radiographs was performed to determine the presence of ectopic bone with complete agreement between reviewers. HO developed in 47\% (16 of 34) of the study patients (Table 1).

To investigate the correlation of gene transcript expression at the mRNA level with functional protein expression and biologic relevance, the presence and concentration of BMP-2 in the effluent of a cohort of 29 wounds (selected based on sample availability; $14 \mathrm{HO}$, 15 non-HO wounds) were determined according to the manufacturer's instructions using the Human BMP-2 ELISA Kit (R\&D Systems, Minneapolis, MN, USA). Data were analyzed on a "per wound" basis, because not every wound in every patient formed HO. BMP-2 was selected for this subset analysis because it is a key regulator of bone formation and its ability to act as a potent osteoinductive agent when targeting osteoprogenitor cell populations has been shown repeatedly in vivo and in vitro $[9,32,38]$.

Statistical differences between continuous variables were evaluated using Student's t-test. Equality of variance for continuous variables was determined using Levene's test. Associations between categorical variables were studied with Fisher's exact test or chi-square analysis as appropriate. Individual samples were compared with an average of control expression values of wounds in which HO did not develop. Transcript quantification was derived using the comparative threshold cycle method and reported as an $\mathrm{n}$-fold difference in the experimental to the control samples [31]. Differential gene expression was considered significant when there was a twofold or greater difference in expression between the two groups and a two-tailed $\mathrm{p}$ value $<0.05$. Differences in gene expression and nonparametric means were evaluated using the Mann-Whitney $\mathrm{U}$ test. The coefficient of determination was used to assess 
Table 1. Patient demographics

\begin{tabular}{|c|c|c|c|c|}
\hline Demographic information & $\begin{array}{l}\text { Number of patients } \\
(\mathrm{N}=34)\end{array}$ & $\begin{array}{l}\text { Heterotopic ossification } \\
(\mathrm{N}=16 ; 47 \%)\end{array}$ & $\begin{array}{l}\text { No heterotopic ossification } \\
(\mathrm{N}=18 ; 53 \%)\end{array}$ & $\mathrm{p}$ value \\
\hline Age (years; mean $\pm \mathrm{SD}$ ) & & $25.4 \pm 6.8$ & $21.8 \pm 4.3$ & $0.086^{\dagger}$ \\
\hline \multicolumn{5}{|l|}{ Sex } \\
\hline Male & 34 & $16(100 \%)$ & $18(100 \%)$ & \multirow[t]{2}{*}{ Not applicable } \\
\hline Female & 0 & 0 & 0 & \\
\hline \multicolumn{5}{|l|}{ Combat theater } \\
\hline Iraq & 26 & $12(75 \%)$ & $14(78 \%)$ & \multirow[t]{2}{*}{$1.0^{*}$} \\
\hline Afghanistan & 8 & $4(25 \%)$ & $4(22 \%)$ & \\
\hline $\begin{array}{l}\text { Evacuation time from theater } \\
\text { in days (mean } \pm \text { SD) }\end{array}$ & & $6.4 \pm 2.9$ & $4.8 \pm 2.2$ & $0.082^{\dagger}$ \\
\hline $\mathrm{BMI}\left(\mathrm{kg} / \mathrm{m}^{2} ;\right.$ mean $\left.\pm \mathrm{SD}\right)$ & & $25.3 \pm 4.3$ & $24.9 \pm 3.6$ & $0.74^{\dagger}$ \\
\hline \multicolumn{5}{|l|}{ Tobacco use } \\
\hline No & 24 & $13(81 \%)$ & $11(61 \%)$ & \multirow[t]{2}{*}{$0.27 *$} \\
\hline Yes & 8 & $3(19 \%)$ & $7(39 \%)$ & \\
\hline Injury Severity Score (mean \pm SD) & & $25.7 \pm 13.4$ & $14.5 \pm 6.8$ & $0.006^{\dagger}$ \\
\hline \multicolumn{5}{|l|}{ Traumatic brain injury } \\
\hline No & 6 & $1(6 \%)$ & $5(28 \%)$ & \multirow[t]{2}{*}{$0.18 *$} \\
\hline Yes & 28 & $15(94 \%)$ & $13(72 \%)$ & \\
\hline
\end{tabular}

* Fisher's exact test; ${ }^{\dagger}$ Student's t-test; BMI = body mass index.

the correlation between mRNA and functional protein levels. Statistical analysis was performed using SPSS Version 16.0 (SPSS Inc, Chicago, IL, USA). Data are represented as mean \pm SEM unless otherwise specified.

\section{Results}

The mean duration of clinical and radiographic followup was 12.4 months (range, 5-17 months). There was no difference in followup between the study cohorts with and without $\mathrm{HO}$ (11.3 months versus 12.5 months; $\mathrm{p}=0.17$ ). There also were no differences with respect to patient demographics between the two groups. The mean Injury Severity Score (ISS) was significantly higher $(\mathrm{p}=0.006)$ in the $\mathrm{HO}$ cohort. Of the 54 total wounds investigated, 24 (44\%) showed radiographic evidence of $\mathrm{HO}$ (Table 2). There were significant differences between the two cohorts in terms of wound healing, size of the wound, presence of a traumatic amputation, and bacterial colonization $(\mathrm{p}<0.05)$.

Several key genes involved in osteogenesis were upregulated at the transcript level in wounds in which $\mathrm{HO}$ developed. Of the 84 osteogenesis-focused gene transcripts analyzed, 13 (ALPL, BMP-2, BMP-3, COL2A1, COLL10A1, COL11A1, COMP, CSF2, CSF3, MMP8, MMP9, SMAD1, VEGFA) were upregulated greater than twofold at the initial débridement in wounds in which $\mathrm{HO}$ developed compared with wounds in which HO did not develop (Table 3). When analyzing transcript levels at the final débridement, transcripts of the same 13 genes were upregulated in wounds in which $\mathrm{HO}$ developed but showed a greater fold change when compared with the initial débridement. Several genes (ANXA5, BGN, COL1A, COL3A1, COL5A1, COL12A1, COL14A1, COL15A1, CTSK, ITGB1, MMP2, SERPINH1) involved in the development and maintenance of the integrity of the extracellular matrix during wound healing were highly expressed in wounds at the initial and final débridements from both cohorts $\left(C_{t} \leq 25\right)$. Because these genes were highly expressed in both groups at the initial and final débridements, we observed no significant change.

Gene expression at the mRNA level correlated directly with functional protein expression. The coefficient of determination $\left(\mathrm{r}^{2}\right)$ for the expression of BMP-2 transcripts in relation to observed concentrations in the wound effluent was 0.76 . Additionally, the effluent of wounds in which HO developed expressed higher levels of BMP-2 compared with wounds in which $\mathrm{HO}$ did not develop. There was no difference in the concentration of BMP-2 in the effluent of both groups at the initial débridement $(\mathrm{p}=0.22$; Fig. 1). However, there was a 2.5 -fold increase in the concentration of BMP-2 in the effluent of wounds in which HO developed at the final débridement $(p=0.029$; Fig. 1). This suggests that BMP-2 may play a critical role in regulating the development of combat-related HO.

\section{Discussion}

Heterotopic ossification is exceedingly common after combat-related extremity trauma. Regardless of etiology, 
Table 2. Wound demographics

\begin{tabular}{|c|c|c|c|c|}
\hline Wound demographic information & $\begin{array}{l}\text { Number of wounds } \\
(\mathrm{N}=54)\end{array}$ & $\begin{array}{l}\text { Heterotopic ossification } \\
(\mathrm{N}=24 ; 44 \%)\end{array}$ & $\begin{array}{l}\text { Number with heterotopic } \\
\text { ossification }(\mathrm{N}=30 ; 56 \%)\end{array}$ & $\mathrm{p}$ value \\
\hline \multicolumn{5}{|l|}{ Mechanism of injury } \\
\hline Gunshot wound & 3 & $1(4 \%)$ & $2(7 \%)$ & \multirow[t]{3}{*}{$0.496^{*}$} \\
\hline Blast & 50 & $22(92 \%)$ & $28(93 \%)$ & \\
\hline Crush & 1 & $1(4 \%)$ & 0 & \\
\hline \multicolumn{5}{|l|}{ Wound outcome } \\
\hline Normal healing & 40 & $12(50 \%)$ & $28(93 \%)$ & \multirow[t]{2}{*}{$<0.001^{*}$} \\
\hline $\begin{array}{l}\text { Impaired healing (delayed closure } \\
\text { or dehiscence) }\end{array}$ & 14 & $12(50 \%)$ & $2(7 \%)$ & \\
\hline $\begin{array}{l}\text { Number of surgical débridements } \\
\quad(\text { mean } \pm \mathrm{SD})\end{array}$ & & $4.5 \pm 3.3$ & $3.2 \pm 2.3$ & $0.135^{\dagger}$ \\
\hline \multicolumn{5}{|l|}{ Wound location } \\
\hline Upper extremity & 12 & $2(8 \%)$ & $10(33 \%)$ & \multirow[t]{2}{*}{$0.167^{*}$} \\
\hline Lower extremity & 42 & $22(92 \%)$ & $20(67 \%)$ & \\
\hline \multicolumn{5}{|l|}{ Traumatic amputation } \\
\hline No & 30 & $9(37 \%)$ & $21(70 \%)$ & \multirow[t]{2}{*}{$0.027 *$} \\
\hline Yes & 24 & $15(63 \%)$ & $9(30 \%)$ & \\
\hline Size of wound $\left(\mathrm{cm}^{3}\right)($ mean $\pm \mathrm{SD})$ & & $613.4 \pm 615.4$ & $173.7 \pm 252.9$ & $0.003^{\dagger}$ \\
\hline \multicolumn{5}{|l|}{ Associated vascular injury } \\
\hline No & 44 & $17(71 \%)$ & $27(90 \%)$ & \multirow[t]{2}{*}{$0.089 *$} \\
\hline Yes & 10 & $7(29 \%)$ & $3(10 \%)$ & \\
\hline \multicolumn{5}{|l|}{ Wound colonization } \\
\hline No & 19 & $2(8 \%)$ & $17(57 \%)$ & \multirow[t]{2}{*}{$<0.001 *$} \\
\hline Yes & 35 & $22(92 \%)$ & $13(43 \%)$ & \\
\hline \multicolumn{5}{|l|}{ Wound closure method } \\
\hline Suture & 41 & $18(75 \%)$ & $23(77 \%)$ & \multirow[t]{2}{*}{$0.741 *$} \\
\hline Skin graft & 13 & $6(25 \%)$ & $7(23 \%)$ & \\
\hline
\end{tabular}

* Fisher's exact test; ${ }^{\dagger}$ Student's t-test; ${ }^{\star}$ chi-square test.

the pathogenesis of $\mathrm{HO}$ is multifactorial and requires the interaction of several biologic mediators and cell types. Efforts to identify the molecular mechanisms associated with its development have focused on the conditions permissive to osteogenesis in the cellular microenvironment $[10,15,29]$. An understanding of these mechanisms could lead to better means of risk stratification and prophylaxis. In this study, we investigated the expression pattern of genes related to osteogenesis in traumatic wounds, compared gene expression levels between cohorts with and without $\mathrm{HO}$, and confirmed that a correlation exists between transcript levels and functional protein expression for BMP-2, a key regulator of bone formation.

The findings of our study must be interpreted in the context of its limitations. First, analysis of transcript expression was performed in a relatively homogeneous population with specific injury patterns and the findings presented may not be applicable to all populations at risk for HO. Second, analysis of selected mRNA transcripts was determined at initial and final débridements and the exact pattern of temporal expression related to the pathogenesis of ectopic bone formation was not determined nor was an analysis of systemic mediators. However, analysis of traumatic wounds at these times provides an accurate assessment of the posttraumatic environment conducive to osteogenesis because in vivo studies have shown fibroproliferative chondrogenesis by 7 days and heterotopic osteogenesis by 14 days after injury [19, 44].

\section{Gene Upregulation in Patients Who Developed} Heterotopic Ossification

The development of HO is theorized to require differentiation of mesenchymal progenitor cells toward chondrocyte and osteoblastic lineage, necessary steps for endochondral ossification [25]. As seen in our study, the expression of transcripts necessary for synthesis of cartilaginous matrix (COL2A1, COL10A1, COL11A1, COMP) and tissue remodeling (MMP8, MMP9) were upregulated in wounds in which $\mathrm{HO}$ developed. Specifically, COL2A1 encodes type II collagen, the chief component of cartilaginous 
Table 3. Gene expression analysis

\begin{tabular}{|c|c|c|c|c|c|c|}
\hline \multirow[t]{2}{*}{ Gene } & \multicolumn{3}{|l|}{ Initial dèbridement } & \multicolumn{3}{|l|}{ Final dèbridement } \\
\hline & $\begin{array}{l}\text { Fold change (normalized } \\
\text { to GAPDH) }\end{array}$ & $95 \% \mathrm{CI}$ & $\mathrm{p}$ value & $\begin{array}{l}\text { Fold change (normalized } \\
\text { to GAPDH) }\end{array}$ & $95 \% \mathrm{CI}$ & $\mathrm{p}$ value \\
\hline ALPL & 4.1 & $3.5-4.8$ & 0.006 & 6.2 & $5.7-6.8$ & 0.054 \\
\hline BMP-2 & 4.8 & $4.3-5.4$ & $<0.001$ & 8.2 & $7.7-8.8$ & $<0.001$ \\
\hline BMP-3 & 2.1 & $1.6-2.5$ & 0.06 & 2.9 & $2.4-3.3$ & 0.083 \\
\hline COL2A1 & 4.7 & $4.2-5.3$ & $<0.001$ & 8.4 & $8.1-8.9$ & 0.004 \\
\hline COL10A1 & 4.3 & $3.6-5.0$ & $<0.001$ & 8.5 & $7.8-9.1$ & 0.001 \\
\hline COL11A1 & 6.0 & $5.1-6.8$ & 0.006 & 10.8 & $9.2-10.4$ & 0.010 \\
\hline COMP & 4.2 & $3.8-4.6$ & 0.02 & 7.9 & $7.3-8.4$ & 0.032 \\
\hline CSF2 & 4.8 & $4.2-5.3$ & 0.003 & 8.7 & $8.2-9.5$ & 0.003 \\
\hline CSF3 & 5.8 & $5.2-6.3$ & 0.012 & 9.2 & $8.5-9.9$ & 0.024 \\
\hline MMP8 & 5.8 & $5.4-6.5$ & $<0.001$ & 9.3 & $8.7-9.6$ & $<0.001$ \\
\hline MMP9 & 4.5 & $4.1-5.1$ & 0.014 & 9.1 & $8.8-9.5$ & 0.03 \\
\hline SMAD1 & 4.4 & $3.9-5.2$ & 0.024 & 8.1 & $7.5-9.0$ & 0.028 \\
\hline VEGF-A & 4.2 & $3.6-4.8$ & 0.017 & 8.3 & $7.8-8.9$ & 0.001 \\
\hline
\end{tabular}

Expression values represented as fold change in wounds in which heterotopic ossification (HO) developed compared with control expression values of wounds in which HO did not develop at initial and final surgical débridements. Differences in gene expression between groups evaluated using the Mann-Whitney $U$ test; $\mathrm{ALPL}=$ alkaline phosphatase, $\mathrm{COL}=$ collagen alpha, $\mathrm{COMP}=$ collagen oligometric matrix protein, $\mathrm{CSF}=$ colony stimulating factor, $\mathrm{MMP}=$ matrix metalloproteinase; SMAD1 = SMAD family member.

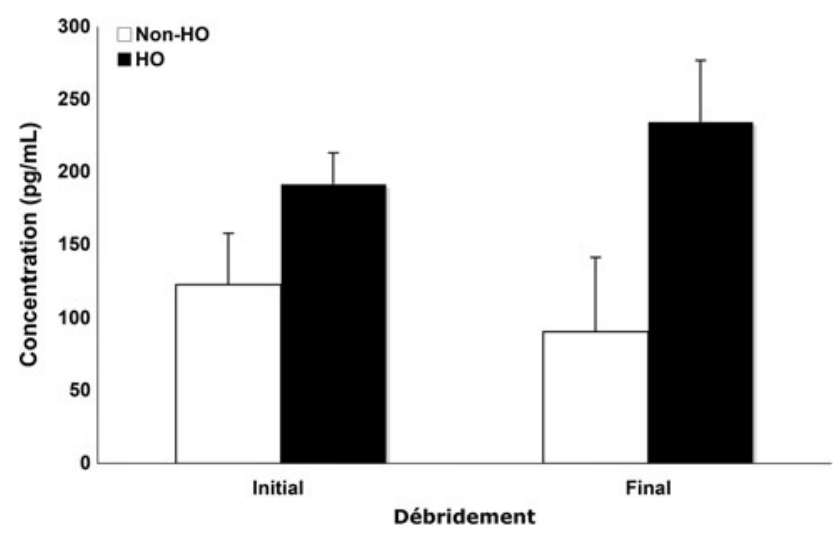

Fig. 1 BMP-2 concentration in the wound effluent is depicted at the initial ( $\mathrm{n}=14 \mathrm{HO}$ wounds, $\mathrm{n}=15$ non-HO wounds) and final débridement ( $\mathrm{n}=14 \mathrm{HO}$ wounds, $\mathrm{n}=15$ non-HO wounds). The débridements are further stratified by wounds in which $\mathrm{HO}$ developed (HO) and wounds in which HO did not develop (non-HO). Data are depicted as mean \pm SEM. $* \mathrm{p}<0.05$.

matrix, whereas COL10A1 encodes type X collagen, a marker for hypertrophic chondrocytes intimately associated with calcification of the cartilaginous matrix [40, 43].

Transcript levels of genes necessary for the growth, remodeling, and maintenance of the extracellular matrix in wound healing were highly expressed in wounds from both groups, suggesting their importance in the pathogenesis of HO. In addition, transcript levels of genes encoding type I collagen (COL1A1, COL1A2), the predominant structural component of bone, also were highly expressed in both groups [43]. Significant differences between the two cohorts, however, were found regarding systemic injury severity and the local inflammatory response to injury. Patients who had HO develop sustained more severe systemic injuries as evident by elevated ISS (Table 1). Furthermore, the increased expression of genes encoding inflammatory cytokines (CSF2/GM-CSF, CSF3/G-CSF) suggests that a more pronounced inflammatory microenvironment is present in wounds in which HO developed. The increased bioburden imparted by bacterial colonization also may contribute to the proinflammatory microenvironment, and we noted a significantly increased rate of critical bacterial colonization in the $\mathrm{HO}$ cohort, similar to that previously described in combat casualties [15]. The expression of mitogenic growth factors and proinflammatory cytokines has also been shown to be upregulated during bacterial colonization and specifically after exposure to lipopolysaccharide [6].

\section{Functional Protein Expression and Heterotopic Ossification}

Soft tissue injury in the setting of a hyperinflammatory response has been shown to contribute substantially to ectopic skeletogenesis [16, 25, 32]. Specifically, the expression of BMP-2 and related osteoinductive morphogens by tissue macrophages and other inflammatory mediators is highly 
upregulated at sites of muscular damage and soft tissue injury $[6,25,41]$. Overactive BMP signaling has been implicated in the development of $\mathrm{HO}[25,46,48]$. Notably, the expression of BMP-2 transcripts was upregulated in wounds that had HO develop at the initial and final débridements. Our findings are consistent with those of previous reports in which muscle injury and associated inflammatory changes were reported as sufficient to trigger the development of ectopic bone in the setting of increased BMP expression [25, 32]. Several human and animal studies have further implicated the role of BMPs and their downstream signaling pathways in the pathogenesis of HO [21, 24, 53]. The upregulation of SMAD1, a gene encoding protein that serves as a signal transducer and transcriptional modulator of BMP signaling, further supports this observation [47].

Angiogenesis is an absolute requirement for endochondral ossification, successful fracture union, and the formation of ectopic bone [1, 5]. Thus, it was not surprising that VEGFA expression was upregulated in wounds in which $\mathrm{HO}$ developed. A hypoxic environment during the early stages of endochondral bone formation is necessary for differentiation of progenitor cells toward chondrocyte lineage $[14,38,50]$. However, the final event in endochondral ossification and ectopic bone growth is replacement of the avascular cartilage template by highly vascularized bone. Hypoxic induction of VEGFA expression necessary for angiogenesis appears to be a ubiquitous response mediated by hypoxia inducible factor- $1 \alpha[30,33]$.

The expression of BMP-2 in wounds in which HO developed also plays a critical role in the expression of VEGFA. The ability of BMPs to increase the levels of VEGFA mRNA in a concentration and time-dependent fashion has been shown [12, 23, 51]. Additional synergy between diffusible osteogenic morphogens and proangiogenic factors has been shown to enhance the rate of ectopic bone growth through modulation of angiogenesis, recruitment and induction of local progenitor cells, and enhancement of cell survival [28, 42]. Increased expression of BMP-2 and VEGFA transcripts in wounds that had ectopic bone develop further emphasizes their importance in the pathogenesis of HO. The ability of BMP antagonists and antiangiogenic therapy to slow or inhibit ectopic bone growth by altering the microenvironment conducive for osteogenesis holds promise for future mechanistic and gene-directed therapy [36, 44, 52].

\section{Conclusions}

Our data suggest the process of ectopic bone formation is initiated shortly after a traumatic insult, findings consistent with those of others $[4,44]$. Wounds in which HO developed exhibited an elevated, protracted inflammatory state and may account for the increased levels of mRNA transcripts observed at the final débridement. A similar trend was noted in the temporal pattern of BMP-2 expression at the protein level. The interactions among the inflammatory response to injury, overexpression of genes related to osteogenesis, and expression of BMPs in the microenvironment parallel the clinical observation of more severe forms of $\mathrm{HO}$ occurring in patients with more severe injuries. Therefore, these results offer the opportunity to use the identified genes as markers to predict the development of $\mathrm{HO}$ in severely injured patients.

We also showed that significantly different osteopromotive gene expression profiles are present in combat-related wounds that have HO develop as compared with similar wounds in which $\mathrm{HO}$ does not form and that mRNA expression correlated directly with functional protein expression in wound effluent for BMP-2. The overexpression of selected gene transcripts related to ectopic matrix mineralization and endochondral bone formation indicates the presence of a microenvironment conducive to osteogenesis in traumatic wounds with BMP-2 potentially serving as a critical regulatory modulator. Continued research into the mechanisms responsible for the formation of $\mathrm{HO}$ is needed to further identify patients at risk and potential therapeutic targets for this and other patient populations.

Acknowledgments We thank Fred Gage CRRP, and Nancy K. Porterfield BS, for their valuable assistance in sample preparation, assay validation, and data compilation. The multidisciplinary care of these patients would not have been possible without the dedicated efforts of everyone at the National Military Medical Center. Civilian and military personnel have rendered skilled and compassionate care for these patients. All of our efforts are dedicated to those who have been placed in harm's way for the good of our nation.

\section{References}

1. Allori RC, Sailon AM, Warren SM. Biological basis of bone formation, remodeling, and repair-part I: biochemical signaling molecules. Tissue Eng Part B Rev. 2008;14:259-273.

2. Bidner SM, Rubins IM, Desjardins JV, Zukor DJ, Gotzman D. Evidence for a humoral mechanism for enhanced osteogenesis after head injury. J Bone Joint Surg Am. 1990;55:1144-1149.

3. Brooker AF, Bowerman JW, Robinson RA, Riley LHJ. Ectopic ossification following total hip replacement. Incidence and a method of classification. J Bone Joint Surg Am. 1973;55: 1629-1632.

4. Burd TA, Hughes MS, Anglen JO. Heterotopic ossification prophylaxis with indomethacin increases the risk of long-bone nonunion. J Bone Joint Surg Br. 2003;85:700-705.

5. Carano RA, Filvaroff EH. Angiogenesis and bone repair. Drug Discov Today. 2003;8:980-989.

6. Champagne CM, Takebe J, Offenbacher S, Cooper LF. Macrophage cell lines produce osteoinductive signals that include bone morphogenetic protein-2. Bone. 2002;30:26-31.

7. Chan KT. Heterotopic ossification in traumatic brain injury. Am J Phys Med Rehabil. 2005;84:145-146. 
8. Chandrasenan J, Dias R, Lunn PG. Heterotopic ossification after the Outerbridge-Kashiwagi procedure in the elbow. J Shoulder Elbow Surg. 2008;17:15-17.

9. Chen D, zhao M, Mundy GR. Bone morphogenetic proteins. Growth Factors. 2004;22:233-241.

10. Davis TA, O'Brien FP, Anam K, Grijalva S, Potter BK, Elster EA. Heterotopic ossification in complex orthopaedic combat wounds: quantification and characterization of osteogenic precursor cell activity in traumatized muscle. J Bone Joint Surg Am. 2011;93:1122-1131.

11. de la Pena LS, Billings PC, Fiori JL, Ahn J, Kaplan FS, Shore EM. Fibrodysplasia ossificans progressiva (FOP), a disorder of ectopic osteogenesis, misregulates cell surface expression and trafficking of bmpria. J Bone Miner Res. 2005;20:1168-1176.

12. Deckers MM, Karperien M, van der Bent C, Yamashita T, Papapoulos SE, Lowik CW. Expression of vascular endothelial growth factors and their receptors during osteoblast differentiation. Endocrinology. 2000;141:1667-1674.

13. Ekelund A, Brosjo O, Nilsson OS. Experimental induction of heterotopic bone. Clin Orthop Relat Res. 1991;263:102-112.

14. Emans PJ, Spaapen F, Surtel DA, Reilly KM, Cremers A, Van Rhijn LW, Bulstra SK, Voncken JW, Kuijer R. A novel in vivo model to study endochondral bone formation; HIF-1alpha activation and bmp expression. Bone. 2007;40:409-418.

15. Evans KN, Forsberg JA, Potter BK, Hawksworth JS, Brown TS, Andersen R, Dunne JR, Tadaki D, Elster EA. Inflammatory cytokine and chemokine expression is associated with heterotopic ossification in high-energy penetrating war injuries. J Orthop Trauma. 2012;26:e204-13.

16. Forsberg JA, Pepek JM, Wagner S, Wilson K, Flint J, Andersen RC, Tadaki D, Stojadinovic A, Elster EA. Heterotopic ossification in high-energy wartime extremity injuries: incidence and risk factors. J Bone Joint Surg Am. 2009;91:1084-1091.

17. Forsberg JA, Potter BK. Heterotopic ossification in wartime wounds. J Surg Orthop Adv. 2010;19:54-61.

18. Furuya H, Ikezoe K, Wang L, Ohyagi Y, Motomura K, Fujii N, Kira J, Fukumaki Y. A unique case of fibrodysplasia ossificans progressiva with an ACVR1 mutation, g356d, other than the common mutation (r206 h). Am J Med Genet A. 2008;146:459-463.

19. Glaser DL, Economides AN, Wang L, Liu X, Kimble RD, Fandl JP, Wilson JM, Stahl N, Kaplan FS, Shore EM. In vivo somatic cell gene transfer of an engineered noggin mutein prevents BMP4-induced heterotopic ossification. J Bone Joint Surg Am. 2003;85:2332-2342.

20. Groppe JC, Shore EM, Kaplan FS. Functional modeling of th EACVR1 (r206 h) mutation in fop. Clin Orthop Relat Res. 2007;462:87-92.

21. Hassel S, Schmitt S, Hartung A, Roth M, Nohe A, Petersen N, Ehrlich M, Henis YI, Sebald W, Knaus P. Initiation of SMADdependent and SMAD-independent signaling via distinct BMPreceptor complexes. J Bone Joint Surg Am. 2003;85(Suppl 3):44-51.

22. Hawksworth JS, Stojadinovic A, Gage FA, Tadaki DK, Perdue PW, Forsberg J, Davis TA, Dunne JR, Denobile JW, Brown TS, Elster EA. Inflammatory biomarkers in combat wound healing. Ann Surg. 2009;250:1002-1007.

23. Kakudo N, Kusumoto K, Wang YB, Iguchi Y, Ogawa Y. Immunolocalization of vascular endothelial growth factor on intramuscular ectopic osteoinduction by bone morphogenetic protein-2. Life Sci. 2006;79:1847-1855.

24. Kan L, Hu M, Gomes WA, Kesler JA. Transgenic mice overexpressing BMP4 develop a fibrodysplasia ossificans progressiva (FOP)-like phenotype. Am J Pathol. 2004;165:1107-1115.

25. Kaplan FS, Glaser DL, Hebela N, Shore EM. Heterotopic ossification. J Am Acad Orthop Surg. 2004;12:116-125.
26. Kaplan FS, Xu M, Seemann P, Connor JM, Glaser DL, Carroll L, Delai P, Fastnacht-Urban E, Forman SJ, Gillessen-Kaesbach G, Hoover-Fong J, Koster B, Pauli RM, Reardon W, Zaidi SA, Zasloff MA, Morhart R, Mundlos S, Groppe JC, Shore EM. Classic and atypical fibrodysplasia ossificans progressiva (FOP) phenotypes are caused by mutations in the bone morphogenetic protein (BMP) type I receptor ACVR1. Hum Mutat. 2008;20: 379-390.

27. Kaysinger KK, Ramp WK, Lang GJ, Gruber HE. Comparison of human osteoblasts and osteogenic cells from heterotopic bone. Clin Orthop Relat Res. 1997;342:181-191.

28. Kempen DH, Lu L, Heijink A, Hefferan TE, Creemers LB, Maran A, Yaszemski MJ, Dhert WJ. Effect of local sequential VEGF and BMP-2 delivery on ectopic and orthotopic bone regeneration. Biomaterials. 2009;30:2816-2825.

29. Kim SY, Choi HY, Myung KB, Choi YW. The expression of molecular mediators in the idiopathic cutaneous calcification and ossification. J Cutan Pathol. 2008;35:826-831.

30. Levy AP, Levy NS, Wegner S, Goldberg MA. Transcriptional regulation of the rat vascular endothelial growth factor gene by hypoxia. J Biol Chem. 1995;270:13333-13340.

31. Livak KJ, Schmittgen TD. Analysis of relative gene expression data using real-time quantitative pcr and the 2(-delta delta $\mathrm{c}[\mathrm{t}]$ ) method. Methods. 2001;25:402-408.

32. Lounev VY, Ramachandran R, Wosczyna MN, Yamamoto M, Maidment AD, Shore EM, Glaser DL, Goldhamer DJ, Kaplan FS. Identification of progenitor cells that contribute to heterotopic skeletogenesis. J Bone Joint Surg Am. 2009;91:652-663.

33. Madan A, Curtin PT. A 24-base-pair sequence $3^{\prime}$ to the human erythropoetin gene contains a hypoxia-responsive transcriptional enhancer. Proc Natl Acad Sci USA. 1993;90:3928-3932.

34. Moed BR, Karges DE. Prophylactic indomethacin for the prevention of heterotopic ossification after acetabular fracture surgery in high-risk patients. J Orthop Trauma. 1994;8:34-39.

35. Moore TJ. Functional outcome following surgical excision of heterotopic ossification in patients with traumatic brain injury. J Orthop Trauma. 1993;7:11-14.

36. Nakamura Y, Wakitani S, Nakayama J, Wakabayashi S, Horiuchi $\mathrm{H}$, Takaoka K. Temporal and spatial expression profiles of bmp receptors and noggin during BMP-2-induced ectopic bone formation. J Bone Miner Res. 2003;18:1854-1862.

37. Nesti LJ, Jackson WM, Shanti RM, Koehler SM, Aragon AB, Bailey JR, Sracic MK, Freedman BA, Giuliani JR, Tuan RS. Differentiation potential of multipotent progenitor cells derived from war-traumatized muscle tissue. J Bone Joint Surg Am. 2008;90:2390-2398.

38. Olmsted-Davis E, Gannon FH, Ozen M, Ittmann MM, Gugala Z, Hipp JA, Moran KM, Fouletier-Dilling CM, Schumara-Martin S, Lindsey RW, Heggeness MH, Brenner MK, Davis AR. Hypoxic adipocytes pattern early heterotopic bone formation. Am J Pathol. 2007; 170:620-632.

39. Potter BK, Burns TC, Lacap AP, Granville RR, Gajewski DA. Heterotopic ossification following traumatic and combat-related amputations. Prevalence, risk factors, and preliminary results of excision. J Bone Joint Surg Am. 2007;89:476-486.

40. Reginato AM, Sanz-Rodriguez C, Jimenez SA. Biosynthesis and characterization of type $\mathrm{x}$ olalgen in human fetal epiphyseal growth plate cartilage. Osteoarthritis Cartilage. 1995;3:105-116.

41. Rifas L, Cheng SL, Shen V, Peck WA. Monokines produced by macrophages stimulate the growth of osteoblasts. Connect Tissue Res. 1989;23:163-178.

42. Samee M, Kasugai S, Kondo H, Ohya K, Shimokawa H, Kuroda $\mathrm{S}$. Bone morphogenetic protein-2 (BMP-2) and vascular endotheslial growth factor (VEGF) transfection to human periosteal cells enhances osteoblastic differentiation and bone formation. J Pharmacol Sci. 2008;108:18-31. 
43. Sandberg M, Autio-Harmainen H, Vuorio E. Localization of the expression of types I, III, and IV collagen, TGF-beta 1 and c-FOS genes in developing human calvarial bones. Dev Biol. 1988;130:324-334.

44. Sawyer JR, Myers MA, Rosier RN, Puzas JE. Heterotopic ossification: clinical and celluar aspects. Calcif Tissue Int. 1991;49: 208-215.

45. Sell S, Gaissmaier C, Fritz J, Herr G, Esenwein S, Kusswetter W, Volkmann R, Wittkowski KM, Rodermann HP. Different behavior of human osteoblast-like cells isolated from normal and heterotopic bone in vitro. Calcif Tissue Int. 1998;62:51-59.

46. Shafritz AB, Shore EM, Gannon FH, Zasloff MA, Taub R, Muenke M, Kaplan FS. Overexpression of an osteogenic morphogen in fibrodysplasia ossificans progressiva. $N$ Engl $\mathrm{J}$ Med. 1996;335:555-561.

47. Shi X, Yang X, Chen D, Chang Z, Cao X. SMAD1 interacts with homeobox DNA-binding proteins in bone morphogenetic protein signaling. J Biol Chem. 1999;274:13711-13717.

48. Shore EM, Glaser DL, Gannon FH. Osteogenic induction in hereditary disorders of heterotopic ossification. Clin Orthop Relat Res. 2000;374:303-316.
49. Simonsen LL, Sonne-Holm S, Krasheninnikoff M, Engberg AW. Symptomatic heterotopic ossification after very severe traumatic brain injury in 114 patients: incidence and risk factors. Injury. 2007;38:1146-1150.

50. Sun $\mathrm{X}$, Wei $\mathrm{Y}$. The role of hypoxia-inducible factor in osteogenesis and chondrogenesis. Cytotherapy. 2009;11: 261-267.

51. Yeh LC, Lee JC. Osteogenic protein-1 increases gene expression of vascualr endotheslial growth factor in primary cultures of fetal rat calvaria cells. Mol Cell Endocrinol. 1999;153: $113-124$.

52. Yin M, Gentili C, Koyama E, Zasloff MA, Pacifici M. Antiangiogenic treatment delays chondrocyte maturation and bone formation during limb skeletogenesis. J Bone Miner Res. 2002;17:56-65.

53. Zhang F, Qiu T, Wu X, Wan C, Shi W, Wang YB, Chen J, Wan M, Clemens TL, Cao X. Sustained BMP signaling in osteoblasts stimulates bone formation by promoting angiogenesis and osteoblast differentiation. J Bone Miner Res. 2009;24: $1224-1233$. 